Volume 2 Nomor. 2, Oktober 2017

P -ISSN : 2541-1179, E-ISSN : 2581-1711

OJS :http://journal.uin-alauddin.ac.id/index.php/instek/index

WFORIATIKASANS DAN TERIOLOEI

Email : instek@uin-alauddin.ac.id

\title{
IMPLEMENTASI OPEN MEETINGS MENGGUNAKAN RASPBERRY PI SEBAGAI SERVER
}

\author{
Nur Afif \\ Dosen Jurusan Teknik Informatika \\ Fakultas Sains \& Teknologi UIN Alauddin Makassar \\ Email : nur.afif@uin-alauddin.ac.id
}

\begin{abstract}
ABSTRAK
Penelitian ini bertujuan adalah membuat suatu rancangan untuk mengimplementasikan suatu aplikasi open meetings dengan memanfaaatkan Raspberry Pi sebagai server aplikasi. Aplikasi ini dibuat sebagai sarana untuk memudahkan pengguna dalam melakukan suatu pertemuan dan saling berkomunikasi

satu sama lain. Pada penelitian ini, jenis penelitian yang digunakan penulis adalah penelitian kualitatif dengan metode Design and Creation dan mengunakan pendekatan saintifik. Teknik pengolahan dan analisis data yang digunakan adalah metode analisis kualitatif, karena penelitian ini menghasilkan data deskriptif berupa kata-kata tertulis. Untuk merancang aplikasi ini digunakan metode waterfall. Teknik pengujian system yang digunakan pada penelitian ini adalah black box testing. Hasil pengujian menunjukkan bahwa sistem open meetings dapat diimplementasikan pada sebuah perangkat Raspberry Pi, dimana Raspberry Pi dapatdigunakan sebagai server dengan pemanfaatan suatu jaringan secara optimal. Sistem ini juga dapat membantu pengguna dalam melakukan suatu pertemuan dan salingberkomunikasi satu sama lain.
\end{abstract}

Kata Kunci : Implementasi, OpenMeetings, Raspberry pi, Conference, Web.

\section{I.PENDAHULUAN}

Dewasa ini, fitur dan layanan teknologi komunikasi sudah demikian maju. Teknologi komunikasi dapat membawa seorang individu melintasi batas ruang dan waktu serta mendapatkan informasi melalui internet yang tidak didapat sebelumnya.

Manusia memiliki keinginan untuk bersosialisasi dan berinteraksi dengan sesamanya, yang dapat dimulai dengan mengadakan suatu pertemuan untuk melakukan suatu komunikasi dengan saling bertukar pikiran pun informasi,mengemukakan suatu pendapat/ide. 
Volume 2 Nomor. 2, Oktober 2017

P -ISSN : 2541-1179, E-ISSN : 2581-1711

OJS :http://journal.uin-alauddin.ac.id/index.php/instek/index

Sebuah perusahaan berkembang selalu mengadakan suatu rapat/pertemuan untuk membahas atau meningkatkan kinerja/mutu perusahaan terkait. Terkadang ketika agenda rapat telah diinformasikan kepada seluruh staf karyawan terkait, terdapat beberapa pihak yang tidak dapat hadir dalam rapat/pertemuan tersebut. Hal ini sangat berpengaruh terhadap hasil rapat yang berlangsung, karena jika ditinjau dari agenda rapat yang dilakukan, mungkin pihak yang tidak dapat hadir sangat berpengaruh dalam rapat pertemuan tersebut.

Pada kasus pengadaan rapat/pertemuan yang dijabarkan tersebut, solusi yang biasanya digunakan dalam suatu instansi berupa penundaan jadwal hingga pembatalan rapat/pertemuan dari jadwal yang telah ditentukan. Ataupun pihak terkait yang tidak bisa hadir dalam rapat/pertemuan tersebut menyerahkan wewenangnya kepada seseorang yang telah dipilih untuk menggantikan kehadirannya pada agenda rapat/pertemuan tersebut. Namun penggunaan solusi tersebut tidaklah efektif dan efisien dalam mengatasi permasalahan terkait pengadaan agenda rapat/pertemuan yang dijadwalkan, karena dapat berdampak pada peningkatan produktifitas yang kurang maksimal dan pemanfaatan waktu, tenaga, serta biaya yang kurang efisien.

Perkembangan teknologi yang semakin pesat membuat kendala itu menjadi teratasi, salah satunya adalah perkembangan teknologi streaming yang dapat diaplikasikan untuk membuat rapat/pertemuan secara online berbasis web yang membuat proses rapat/pertemuan tidak berpusat pada satu tempat atau tidak harus berada diruangan yang sama. Sehingga dapat meminimalkan dan mendukung penggunaan waktu, biaya, serta tenaga yang lebih efisien. Dalam mencapai tujuan tersebut, salah satunya dapat didukung dengan adanya suatu aplikasi yang berbasis open source yang disebut dengan open meetings.

Open meetings yaitu sistem secara virtual di mana masing-masing anggota rapat tidak harus bertatap muka dalam suatu ruangan rapat tetapi dapat digantikan dengan teknologi streaming berbasis web dengan memanfaatkan jaringan internet/intranet. Agar aplikasi open meetings tersebut dapat berjalan, maka dibutuhkan suatu perancangan server sebagai penghubung jaringan. 
Volume 2 Nomor. 2, Oktober 2017

P-ISSN : 2541-1179, E-ISSN : 2581-1711

OJS :http://journal.uin-alauddin.ac.id/index.php/instek/index

Pada perancangan server sistem ini akan dibuat dengan menggunakan Raspberry pi, di mana Raspberry pi merupakan komputer papan tunggal (Single Board Circuit/SBC) yang memiliki ukuran sebesar kartu kredit yang dapat digunakan untuk berbagai keperluan seperti spreadsheet, game, bahkan bisa digunakan sebagai media player karena kemampuannya dalam memutar video high definition. Sehingga penggunaan Raspberry pi pada perancangan aplikasi ini sangat mendukung.

Berdasarkan uraian di atas maka pada penelitian ini, akan dibuat suatu perancangan untuk Mengimplementasikan Aplikasi Open meetings dengan Menggunakan Rasbperry Pi sebagai Server. Diharapkan aplikasi ini dapat membantu dalam memudahkan para pimpinan dan staf karyawan dalam mengadakan suatu rapat/pertemuan untuk berkomunikasi satu sama lain.

\section{METODE PENELITIAN}

\section{A. Jenis Penelitian}

Dalam melakukan penelitian ini, jenis penelitian kualitatif lapangan dimana strategis yang digunakan adalah Design and Creation. Dipilihnya jenis penelitian ini karena konsep dari Design and Creation sangat tepat untuk mengelola penelitian ini.

\section{B. Instrumen Penelitian}

Adapun instrument penelitian yang digunakan dalam penelitian yaitu :

\section{Perangkat Keras}

Perangkat keras yang digunakan untuk mengembangkan dan mengumpulkan data pada aplikasi ini adalah Raspberry Pi, SD Card 8 GB, Adapter 3A, dan Laptop

Asus A45VD-VX247D.

\section{Perangkat Lunak}

Adapun perangkat lunak yang digunakan dalam perancangan ini adalah JDK/JRE, Sistem Operasi Debian, MySQL, Putty, VncViewer. 
Volume 2 Nomor. 2, Oktober 2017

P-ISSN : 2541-1179, E-ISSN : 2581-1711

OJS :http://journal.uin-alauddin.ac.id/index.php/instek/index

Email : instek@uin-alauddin.ac.id

\section{C.Perancangan Sistem}

1. Perancangan Perangkat Keras



Gambar 1.Diagram Blok Raspberry pi pada Sistem

\section{HASIL DAN PEMBAHASAN}

\section{A. Implementasi Sistem}

\section{Interface Login}

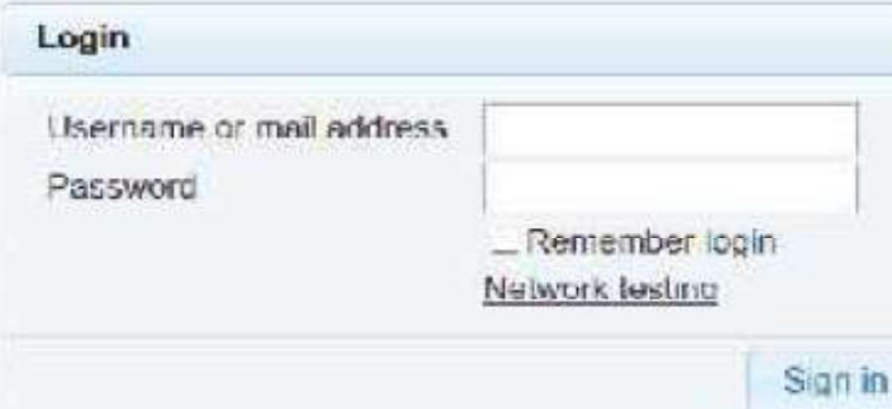

Gambar 2. Interface Login 
Volume 2 Nomor. 2, Oktober 2017

P-ISSN : 2541-1179, E-ISSN : 2581-1711

OJS :http://journal.uin-alauddin.ac.id/index.php/instek/index Email : instek@uin-alauddin.ac.id

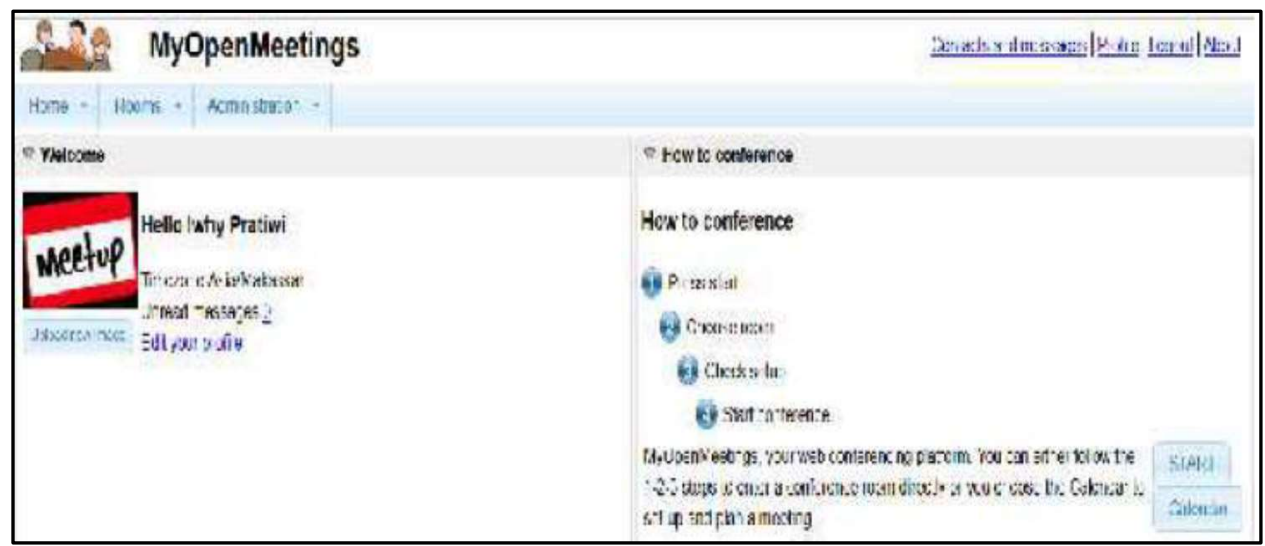

Gambar 3. Antarmuka Home-Dashboard

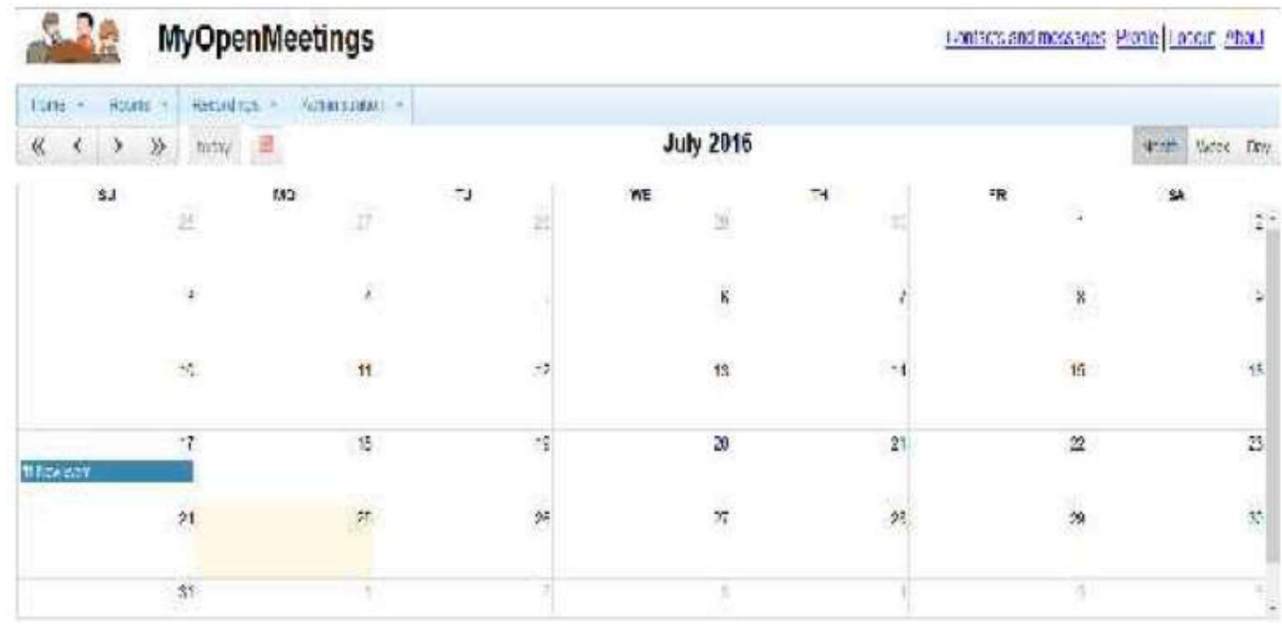

Gambar 4.Antarmuka Home-Calender 
Volume 2 Nomor. 2, Oktober 2017

P-ISSN : 2541-1179, E-ISSN : 2581-1711

OJS :http://journal.uin-alauddin.ac.id/index.php/instek/index

MFORNATIKASANIS DAN TERNOLOG

Email : instek@uin-alauddin.ac.id

\section{B. Hasil Pengujian}

Tabel.1 .Pengujian Menu Login

\begin{tabular}{|l|l|c|}
\multicolumn{1}{|c|}{ Data masukan } & \multicolumn{1}{|c|}{ Yang diharapkan } & \multicolumn{1}{c|}{ Status } \\
\hline $\begin{array}{l}\text { Menginput username } \\
\text { dan password dan } \\
\text { tombol login ditekan. }\end{array}$ & $\begin{array}{l}\text { Akan menampilkan antarmuka } \\
\text { halaman menu utama (Home) }\end{array}$ & $\begin{array}{l}{[\sqrt{ }] \text { Sukses }} \\
{[] \text { Gagal }}\end{array}$ \\
\hline
\end{tabular}

Tabel.2. Pengujian Menu Home

\begin{tabular}{|l|l|l|}
\hline \multicolumn{1}{|c|}{ Data masukan } & \multicolumn{1}{c|}{ Yang diharapkan } & \multicolumn{1}{c|}{ Status } \\
\hline $\begin{array}{l}\text { Menekan list } \\
\text { Dashboard }\end{array}$ & $\begin{array}{l}\text { Menampilkan antarmuka dashboard } \\
\text { yang terdiri dari profil dan how to } \\
\text { conference }\end{array}$ & $\begin{array}{l}\text { [ }] \text { Sukses } \\
{[\text { ] Gagal }}\end{array}$ \\
\hline $\begin{array}{l}\text { Menekan list } \\
\text { Calender }\end{array}$ & $\begin{array}{l}\text { Akan menampilkan kalender dan event } \\
\text { details untuk menambah event dan } \\
\text { menampilkan informasi event yang } \\
\text { ada. }\end{array}$ & $\begin{array}{l}\text { [ }] \text { Sukses } \\
\text { [ ] Gagal }\end{array}$ \\
\hline $\begin{array}{l}\text { Menekan tombol save } \\
\text { pada form event } \\
\text { details }\end{array}$ & $\begin{array}{l}\text { Akan menyimpan informasi events } \\
\text { pada calender }\end{array}$ & $\begin{array}{l}\text { [ }] \text { Sukses } \\
{[\text { ] Gagal }}\end{array}$ \\
\hline
\end{tabular}

Tabel 3. Pengujian Menu Rooms

\begin{tabular}{|l|l|l|}
\hline \multicolumn{1}{|c|}{ Data masukan } & \multicolumn{1}{|c|}{ Yang diharapkan } & \multicolumn{1}{c|}{ Status } \\
\hline $\begin{array}{l}\text { Menekan list Public } \\
\text { Rooms }\end{array}$ & $\begin{array}{l}\text { Akan menampilkan antarmuka public } \\
\text { rooms }\end{array}$ & $\begin{array}{l}{[\sqrt{ }] \text { Sukses }} \\
{[\text { ] Gagal }}\end{array}$ \\
\hline $\begin{array}{l}\text { Menekan tombol } \\
\text { Enter }\end{array}$ & $\begin{array}{l}\text { Akan menampilkan antarmuka } \\
\text { konferensi pertemuan (conference } \\
\text { meeting). }\end{array}$ & $\begin{array}{l}{[\sqrt{ }] \text { Sukses }} \\
{[\text { ] Gagal }}\end{array}$ \\
\hline $\begin{array}{l}\text { Menekan list Private } \\
\text { Rooms }\end{array}$ & $\begin{array}{l}\text { Akan menampilkan antarmuka private } \\
\text { rooms }\end{array}$ & $\begin{array}{l}{[\sqrt{ }] \text { Sukses }} \\
{[\text { ] Gagal }}\end{array}$ \\
\hline
\end{tabular}


Volume 2 Nomor. 2, Oktober 2017

P -ISSN : 2541-1179, E-ISSN : 2581-1711

OJS :http://journal.uin-alauddin.ac.id/index.php/instek/index

Email : instek@uin-alauddin.ac.id

Tabel 4. Pengujian Menu Profil

\begin{tabular}{|c|l|c|}
\hline \multicolumn{1}{|c|}{ Data masukan } & \multicolumn{1}{|c|}{ Yang diharapkan } & \multicolumn{1}{c|}{ Status } \\
\hline Menekan tab profil & $\begin{array}{l}\text { Akan menampilkan form } \text { user details } \\
\text { dan mengedit data-data } \text { user sesuai } \\
\text { yang login. }\end{array}$ & $\begin{array}{l}\text { [ } \sqrt{ } \text { ] Sukses } \\
{[\text { ] Gagal }}\end{array}$ \\
\hline
\end{tabular}

Tabel 5. Pengujian Menu Administrasi

\begin{tabular}{|l|l|l|}
\hline \multicolumn{1}{|c|}{ Data masukan } & \multicolumn{1}{c|}{ Yang diharapkan } & \multicolumn{1}{c|}{ Status } \\
\hline $\begin{array}{l}\text { Menginput data sesuai } \\
\text { dengan yang terdapat } \\
\text { pada halaman input } \\
\text { data dan menekan } \\
\text { tombol simpan }\end{array}$ & $\begin{array}{l}\text { Data yang telah diinput berhasil } \\
\text { tersimpan pada database }\end{array}$ & $\begin{array}{l}\text { [ }] \text { Sukses } \\
\text { [ ] Gagal }\end{array}$ \\
\hline & antarmuka about & {$[$ ] Gagal } \\
\hline
\end{tabular}


Volume 2 Nomor. 2, Oktober 2017

P-ISSN : 2541-1179, E-ISSN : 2581-1711

OJS :http://journal.uin-alauddin.ac.id/index.php/instek/index

WFORIATIKASANSOANTEROLOCG

Email : instek@uin-alauddin.ac.id

Tabel.7. Pengujian Menu Logout

\begin{tabular}{|l|l|l|}
\multicolumn{1}{|c|}{ Data masukan } & \multicolumn{1}{|c|}{ Yang diharapkan } & \multicolumn{1}{c|}{ Status } \\
\hline $\begin{array}{l}\text { Menekan tab logout } \\
\text { dan menekan tombol } \\
\text { Ok }\end{array}$ & $\begin{array}{l}\text { User keluar dari aplikasi (Aplikasi } \\
\text { berhenti dijalankan) }\end{array}$ & $\begin{array}{l}{[\sqrt{ }] \text { Sukses }} \\
{[\text { ] Gagal }}\end{array}$ \\
\hline $\begin{array}{l}\text { Menekan tab logout } \\
\text { dan menekan tombol } \\
\text { Cancel }\end{array}$ & $\begin{array}{l}\text { Akan kembali ke ke form yang dipilih } \\
\text { sebelumnya. }\end{array}$ & $\begin{array}{l}{[\sqrt{ }] \text { Sukses }} \\
{[\text { ] Gagal }}\end{array}$ \\
\hline
\end{tabular}

C. Pengujian Kepada Pengguna

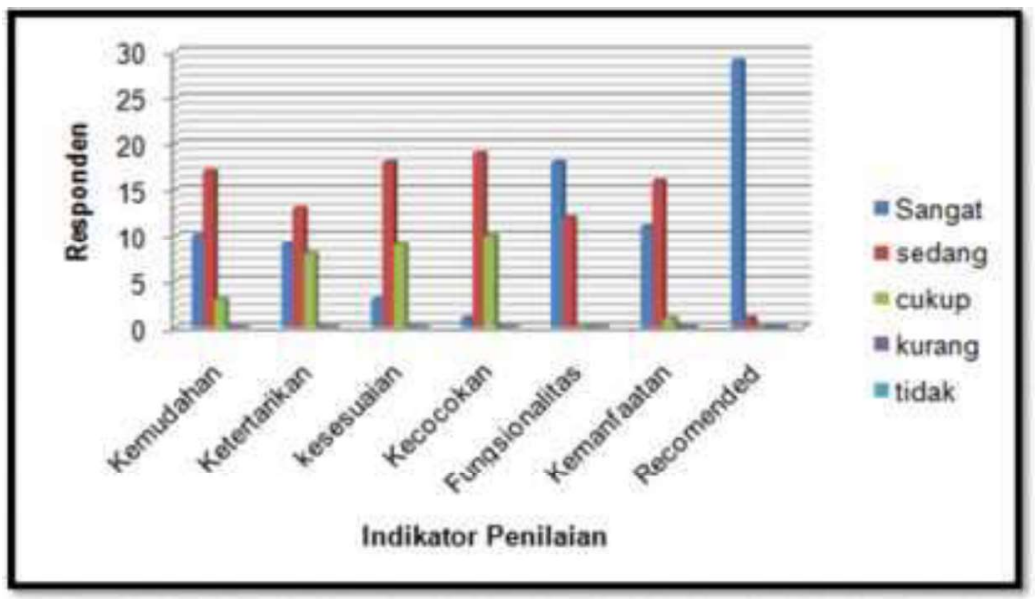

Gambar 5. Diagram Pengujian kepada Pengguna

\section{Pembahasan}

Berdasarkan diagram hasil kuisioner di atas dapat ditarik pernyataan bahwa $33,33 \%$ responden menyatakan aplikasi Openmeetings sangat mudah digunakan, $56,67 \%$ menyatakan mudah dan 10\% menyatakan cukup mudah digunakan. $30 \%$ menyatakan sangat tertarik, 43,33\% tertarik dan 26,67\% meyatakan cukup tertarik. $60 \%$ responden meyatakan aplikasi ini berfungsi dengan sangat baik dan 40\% menyatakan berfungsi. 39,28\% responden menyatakan aplikasi ini sangat bermanfaat, $57,14 \%$ menyatakan bermanfaat dan 3,57\% menyatakan cukup 
Volume 2 Nomor. 2, Oktober 2017

P-ISSN : 2541-1179, E-ISSN : 2581-1711

OJS :http://journal.uin-alauddin.ac.id/index.php/instek/index

INFORIATIKASANS DAN TERNOLOG

Email : instek@uin-alauddin.ac.id

bermanfaat. 96,67\% responden menyatakan sangat merekomendasikan aplikasi Openmeetings dan hanya 3,33\% yang meyatakan biasa saja.

\section{KESIMPULAN}

1. Sistem ini berjalan sesuai dengan fungsinya yaitu dapat melakukan proses pertemuan/rapat dalam bentuk video conference berbasis web.

2. Sistem ini dapat diimplementasikan pada perangkat Raspberry Pi sesuai dengan tujuan penelitian yang dilakukan. Sehingga sistem dapat diimplementasikan pada sistem operasi windows sekalipun.

3. Sistem ini mudah digunakan sehingga tidak kesulitan ketika menggunakan sistemnya (user friendly).

4. Berdasarkan hasil pengujian dengan teknik kuisioner dapat disimpulkan bahwa 90,65 \% responden merekomendasikan sistem OpenMeetings dalam pengimplementasiannya pada perangkat Raspberry Pi.

\section{DAFTAR PUSTAKA}

Abrar, Husein. Manajemen Proyek, Perencanaan, Penjadwalan \& Pengendalian Proyek. Yogyakarta : Andi. 2008.

Ahira, Ana. Pengertian dan penggunaan website secara umum. Jakarta : Toko Gunung Agung. 2008.

Ali, Maskur. Pengertian Internet dan Sejarah Internet. Yogyakarta: Kanisius, 2010 .

Azikin, A, Debian GNU / LINUX. Bandung: Informatika Bandung, 2011.

Dawood, Rahmad, Analisis Kelayakan Raspberry Pi sebagai Web Server. Skripsi. Banda Aceh: Fakultas Teknik Universitas Syiah Kuala, 2014.

Dewanto, I. Joko. Web Desain (Metode Aplikasi dan Implementasi). Yogyakarta: Graha Ilmu, 2006

Kesrul, M. Meeting, Incentive Trip, Conference, Exhibition. Yogyakarta: PT Prenhallindo. 2004. 
Volume 2 Nomor. 2, Oktober 2017

P-ISSN : 2541-1179, E-ISSN : 2581-1711

OJS :http://journal.uin-alauddin.ac.id/index.php/instek/index

Email : instek@uin-alauddin.ac.id

Machfoedz, Mahmud. Rapat dan Presentasi Lisan yang Efektif. Yogjakarta: C.V. Andi Offset. 2005.

Mahmud D, Purwanto, Membangun Web Server dengan Linux. Jakarta: PT Elex Media Komputindo. 2002.

Moelong, J. Lexi, Metodologi Penelitian Kualitatif, Bandung: Remaja Karya, 2002 .

Nasrullah, Membangun Server Open Meeting Lokal Menggunakan Linux Ubuntu Pada U'Budiyah Indonesia. Skripsi. Banda Aceh: STMIK U'budiyah Indonesia, 2012.

Nugroho, B., Trik dan Rahasia Membuat Aplikasi Web dengan PHP, Yogyakarta:Gava Media,2007.

Pressman, Roger. S, Software Engineering: A Practitioner's Approach, Fifth Edition.

United State: McGraw Hill Companies, Inc, 2001. 